\title{
Gas seepage pockmark microbiomes suggest the presence of sedimentary coal seams in the Öxarfjörður graben of NE-Iceland
}

\author{
Guðný Vala Porsteinsdóttir ${ }^{1,2}$, Anett Blischke ${ }^{3}$, M. Auður Sigurbjörnsdóttir ${ }^{1}$, Finnbogi Óskarsson ${ }^{4}$, \\ Pórarinn Sveinn Arnarson ${ }^{5 \dagger}$, Kristinn P. Magnússon ${ }^{1,2,6}$, and Oddur Vilhelmsson ${ }^{1,6,7}$
}

\author{
${ }^{1}$ University of Akureyri, Faculty of Natural Resource Sciences, Borgir v. Nordurslod, 600 \\ Akureyri, Iceland. \\ ${ }^{2}$ Icelandic Institute of Natural History, Borgir v. Nordurslod, 600 Akureyri, Iceland \\ ${ }^{3}$ Iceland GeoSurvey, Branch at Akureyri, Rangarvollum, 603 Akureyri, Iceland \\ ${ }^{4}$ Iceland GeoSurvey, Department of Geothermal Engineering, Grensasvegi 9, 108 Reykjavik, \\ Iceland \\ ${ }^{5}$ Orkustofnun / The Icelandic Energy Authority, Grensasvegi 9, 108 Reykjavik, Iceland \\ (†Passed away) \\ ${ }^{6}$ Biomedical Center, University of Iceland, Vatnsmyrarvegur 16, 101 Reykjavik, Iceland \\ ${ }^{7}$ School of Biological Sciences, The University of Reading, Earley, Reading RG6 6AS, United \\ Kingdom
}

Correspondence: Oddur Vilhelmsson, oddurv@unak.is 


\section{$\underline{\text { Abstract }}$}

Natural gas seepage pockmarks are found off and onshore in the Öxarfjörður graben, NE Iceland. The bacterial communities of two onshore seepage sites were analysed by amplicon sequencing of $16 \mathrm{~S}$ rDNA, along with determining the geochemical characteristics, hydrocarbon content and the carbon isotope composition of the sites.

While one site was found to be characterised by biogenic origin of methane gas, with carbon isotope ratio $\delta^{13} \mathrm{C}[\%]=-63.2$, high content of organic matter and complex hydrocarbons, the other site showed a mixed origin of the methane gas $\left(\delta^{13} \mathrm{C}[\%]=-26.6\right)$ with geothermal characteristics and lower organic matter content. While both sites harboured Proteobacteria as the most abundant bacterial phyla, the Deltaproteobacteria were more abundant at the geothermal site, and the Alphaproteobacteria at the biogenic site. The Dehalococcoidia class of the Chloroflexi phylum was abundant at the geothermal site while the Anaerolineae class was more abundant at the biogenic site. Bacterial strains from the seepage pockmarks were isolated on a variety of selective media targeting bacteria with bioremediation potential. A total of 106 strains were isolated and characterised, including representatives from the phyla Proteobacteria, Bacterioidetes, Firmicutes, and Actinobacteria. This article describes the first microbial study on gas seepage pockmarks in Iceland.

Keywords: Bacterial community analysis, Coal-bed associated microbiota, Bioprospecting, Environmental microbiology, Microbial ecology 


\section{$\underline{\text { Introduction }}$}

Natural gas seepage, the emission of gaseous hydrocarbons from the subsurface, has been studied extensively in the context of petroleum exploration because it can be used as an indicator of petroleum generation in subsurface sediments (1-3). Natural methane gas seepage is the result of subsurface generation or accumulation of methane and the methane concentration in the gas varies according to its source (4). At geothermal and hydrothermal sites, methane is generated by thermogenic processes and seeps up to the surface through cracks and pores, whereas, in deep sea sediments the accumulation of methane can result in cold seeps or methane hydrates where no direct input of heat is found. This is often linked to biogenic methane which is a product of microbial processes in various anaerobic environments, like bog lakes and sea sediments $(5,6)$. In many cases the methane generation is of mixed origin, that is both thermogenic and biogenic. For example, methane that is formed during early coalification processes (coal bed methane) is not only of thermogenic origin but also produced by microbes utilizing the lignite (7). In these environments one would expect to find microbes that participate in methanogenesis and are capable of methane oxidation, respectively.

Where natural methane gas seepage is active, pockmarks can develop that can be described as craters that are formed when gas or liquid comes seeping up from the subsurface (56). Gas seepage pockmarks can be regarded as hotspots for anaerobic oxidation of methane (AOM) that is often dependent on archaea and sulphate-reducing bacteria (47), but can in some cases be driven by bacteria through intra-aerobic-denitrification (9), or possibly reductive dehalogenation, as suggested in a recent study on an ice-covered Antarctic lake (10). Microbial communities of hydrocarbon gas seepage environments have been studied around the world, including the Gulf of Mexico (11), Pacific Ocean Margin (12), Cascadia Margin (13) and the Barents Sea (14), mainly because of their sulfatereducing capabilities and $\mathrm{AOM}$.

In Öxarfjörður bay, NE Iceland, natural gas seepage pockmarks are found both on the seafloor and on shore. Öxarfjörður is located along the lithospheric boundaries of the North-American and the Eurasian plates and forms a graben bounded by the Tjörnes Fracture Zone in the west and the eastern 
rim of the North Iceland Volcanic Zone in the east. Geothermal activity in Öxarfjörður bay is confined to three major fissure swarms, cross-sectioning the volcanic zone. The area is prevailed by the river delta of Jökulsá-á-Fjöllum, causing the Öxarfjörður bay to be even more dynamic in nature. Geological settings in the Öxarfjörður area were studied extensively in the 1990s (15-18), leading to the discovery that the methane-rich seepage gas likely originates from thermal alteration of lignite and coal seams from beneath the $1 \mathrm{~km}$ thick sediment (18). Taken together, these studies strongly suggest the presence of sedimentary lignite in the Öxarfjörður graben (19).

Very little geomicrobiological work has thus far been conducted in Iceland, with most environmental microbiology work being bioprospective in nature, often paying little attention to community structures or biogeochemical activity. Natural gas seeps such as those found in Öxarfjörður, have thus far not been investigated from a microbiological standpoint despite their unique character which makes them ideal for geomicrobiological studies as both sparsely vegetated geothermal gas seepage pockmarks and colder, more vegetated seeps are found in close proximity to one another. Each methane seep system is thought to be unique in terms of the composition of geological and biological features (8), so taking a snapshot of the microbial community at a methane gas seepage site can provide valuable insight into the dynamics of the system and initiate biological discoveries.

In this article, which has been available in preprint form (60), we report the first microbial analysis of the natural gas seepage pockmarks in Öxarfjörður. Hypothesizing that the microbial community in this environment ought to be dominated by methane oxidizing microbes, we performed microbial community analysis on 16S rRNA gene amplicon libraries from two sites differing in visible vegetation and complex hydrocarbon content. Further hypothesizing that these environments would be a source of hydrocarbon-degrading bacteria, we isolated a collection of microbes on various media and tested them for degradation of naphthalene.

\section{Materials and methods}

\section{Sampling and in-field measurements}


Samples were collected at Skógalón (site SX, 66 $09^{\prime} \mathrm{N}, 16^{\circ} 37^{\prime} \mathrm{W}$ ) on August 21st, 2014, and on September 11th, 2015, and at Skógakíll (site AEX, 66¹0'N, 16³4'W) on August 13th, 2015 (Fig. 1). At site SX, where the natural gas seepage pockmarks are somewhat difficult to distinguish from ordinary marsh gas pockmarks, sites were selected where pockmarks were visibly active and appeared to form straight lines extending NW-SE. Temperature, $\mathrm{pH}$ and conductivity were measured in-situ during sampling with hand-held meters. Sediment samples were collected from shallow cores $(50 \mathrm{~cm})$ obtained using a corer constructed from a 3-cm diameter galvanized-iron pipe that was hammered into the ground using a sledgehammer, and transferred aseptically and mixed in sterile, airtight IsoJars (IsoTech laboratories, Champaign, Illinois), according to manufacturer's protocol. Surface soil samples were collected aseptically directly into sterile IsoJars. Water samples were collected aseptically into sterile glass bottles. Gas samples were collected into evacuated double-port glass bottles by means of an inverted nylon funnel connected to silicone rubber tubing. All samples for microbial analysis were immediately put on dry ice where they were kept during transport to laboratory facilities at University of Akureyri where they were either processed immediately or stored in a freezer at $-18^{\circ} \mathrm{C}$ until processing. Samples collected, along with in-situ measurements and types of sample are listed in Table 1.

\section{Chemical analysis of geothermal fluids}

Dissolved sulphide in the water samples was determined on-site by titration with mercuric acetate using dithizone in acetone as indicator (48). Major components in the water samples were determined at the laboratories of Iceland GeoSurvey (ÍSOR) in Reykjavík: Dissolved inorganic carbon was determined by alkalinity titration ( $\mathrm{pH} 8.2$ to 3.8), purging with nitrogen gas and back-titration ( $\mathrm{pH} 3.8$ to 8.2 ) as described previously (48). Silica was analysed by colorimetric determination of a silicamolybdate complex at $410 \mathrm{~nm}$ using a Jenway 6300 spectrophotometer. Total dissolved solids were determined by gravimetry. Anions were determined by suppressed ion chromatography on a ThermoScientific ICS-2100 with an AS-20 column. Major metals were analysed by atomic absorption spectrometry on a Perkin Elmer 1100B spectrometer. The composition of dry gas was also determined 
at the ÍSOR laboratories by gas chromatography on a Perkin Elmer Arnel 4019 light gas analyser equipped with HayeSep and MolSieve columns and three TCDs.

The concentration of trace elements in water samples were determined by ICP methods at the ALS Laboratories, Luleå, Sweden. Stable water isotopes $\left({ }^{2} \mathrm{H}\right.$ and $\left.{ }^{18} \mathrm{O}\right)$ were determined by mass spectrometry using a Delta V Advantage IRMS coupled with a Gasbench II at the Institute of Earth Sciences, University of Iceland.

Headspace gas analysis from sediment samples was performed at Applied Petroleum Technologies, Kjeller, Norway, using standard techniques. Briefly as follows:

Sample preparation and extraction. Sediment samples were washed in water to remove mud before extraction using a Soxtec Tecator instrument. Thimbles were pre-extracted in dichloromethane with 7\% (vol/vol) methanol, $10 \mathrm{~min}$ boiling and $20 \mathrm{~min}$ rinsing. The crushed sample was weighed accurately in the pre-extracted thimbles and boiled for 1 hour and rinsed for 2 hours in $80 \mathrm{cc}$ of dichloromethane with 7\% ( $\mathrm{vol} / \mathrm{vol})$ methanol. Copper blades activated in concentrated hydrochloric acid were added to the extraction cups to cause free sulphur to react with the copper. An aliquot of $10 \%$ of the extract was transferred to a pre-weighed bottle and evaporated to dryness. The amount of extractable organic matter (EOM) was calculated from the weight of this $10 \%$ aliquot.

Deasphaltening. Extracts were evaporated almost to dryness before a small amount of dichloromethane ( 3 times the amount of EOM) was added. Pentane was added in excess (40 times the volume of EOM/oil and dichloromethane). The solution was stored for at least 12 hours in a dark place before the solution was filtered or centrifuged and the weight of the asphaltenes measured.

GC analysis of gas components. Aliquots of the samples were transferred to exetainers where 0.1-1 $\mathrm{ml}$ were sampled using a Gerstel MPS2 autosampler and injected into a Agilent 7890 RGA GC equipped with Molsieve and Poraplot Q columns, a flame ionisation detector (FID) and 2 thermal conductivity detector (TCD). Hydrocarbons were measured by FID. $\mathrm{H}_{2}, \mathrm{CO}_{2}, \mathrm{~N}_{2}$, and $\mathrm{O}_{2} / \mathrm{Ar}$ by TCD.

Carbon isotope analysis of hydrocarbon compounds and $\mathrm{CO}_{2}$. The carbon isotopic composition of the hydrocarbon gas components was determined by a GC-C-IRMS system. Aliquots were sampled with a syringe and analysed on a Trace GC2000, equipped with a Poraplot Q column, 
connected to a Delta plus XP IRMS. The components were burnt to $\mathrm{CO}_{2}$ and water in a $1000{ }^{\circ} \mathrm{C}$ furnace over $\mathrm{Cu} / \mathrm{Ni} / \mathrm{Pt}$. The water was removed by Nafion membrane separation. Repeated analyses of standards indicate that the reproducibility of $\delta^{13} \mathrm{C}$ values is better than $1 \%$ PDB (2 sigma).

Carbon isotope analysis of low concentration methane using the Precon. The carbon isotopic composition of methane was determined by a Precon-IRMS system. Aliquots were sampled with a GCPal autosampler where $\mathrm{CO}_{2}, \mathrm{CO}$ and water were removed on chemical traps. Other hydrocarbons than $\mathrm{CH}_{4}$ and remaining traces of $\mathrm{CO}_{2}$ were removed by cryotrapping. The methane was burnt to $\mathrm{CO}_{2}$ and water in a $1000{ }^{\circ} \mathrm{C}$ furnace over $\mathrm{Cu} / \mathrm{Ni} / \mathrm{Pt}$. The water was removed by Nafion membrane separation. The sample preparation system described (Precon) was connected to a Delta plus XP IRMS for $\delta^{13} \mathrm{C}$ analysis. Repeated analyses of standards indicate that the reproducibility of $\delta^{13} \mathrm{C}$ values is better than $1 \%$ PDB (2 sigma).

GC of EOM fraction. A HP7890 A instrument was used. The column was a CP-Sil-5 CB-MS, length $30 \mathrm{~m}$, i.d. $0.25 \mathrm{~mm}$, film thickness $0.25 \mu \mathrm{m}$. C20D42 is used as an internal standard. Temperature programme: $50^{\circ} \mathrm{C}(1 \mathrm{~min}),-4{ }^{\circ} \mathrm{C} / \mathrm{min},-320^{\circ} \mathrm{C}(25 \mathrm{~min})$.

\section{Bacterial community analysis}

Total DNA was extracted from $50 \mathrm{~cm}$ deep sediment samples in duplicates, using the PowerSoil kit (MoBio laboratories) following the manufacturer's protocol. The DNA isolated was measured with Qubit fluorometer (Invitrogen, Carlsbad, CA) to confirm dsDNA in the samples. Four replicates from AEX1 and four from SX1 (Table 1.) were used to construct a paired-end library of the 16S rDNA hypervariable region V3/V4, using primers 337F and 805R, and sequenced on Illumina MiSeq platform by Macrogen, Netherlands. The data was processed and analysed using CLC Genomics Workbench 12.0 (https://www.qiagen bioinformatics.com/) and the CLC Microbial Genomics Module 4.0, with default parameters. Operational taxonomic units (OTU) were clustered by reference based OTU clustering using the SILVA 16S database v.132 for 97\% similarity, allowing creation of new OTUs (de novo). For statistical analysis only alpha-diversity of samples was performed since the sequencing data only contained technical replicates, which does not allow analyses of beta-diversity. 
Differential abundance analysis (Likelihood Ratio test) was performed to see statistically significant differences in taxa between sampling sites.

\section{Initial culturing and isolation of bacteria}

Samples were serially diluted to $10^{-6}$ in sterile Butterfield's buffer and all dilutions plated in duplicate onto Reasoner's agar 2A (Difco) and several selective and differential media including medium 9K for iron oxidizers (21), Mn medium for manganese oxidizers (990 mL basal agar B [0.42 g NaOAc, $0.1 \mathrm{~g}$ peptone, $0.1 \mathrm{~g}$ yeast extract, $15 \mathrm{agar}, 990 \mathrm{~mL}$ sample water, autoclaved and cooled to $50^{\circ} \mathrm{C}$ ], $10 \mathrm{~mL}$

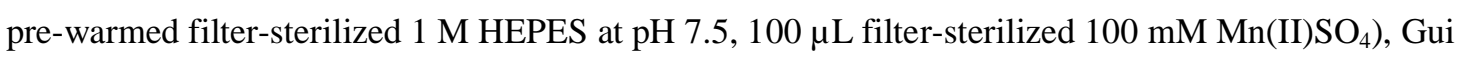
medium for laccase producers (990 $\mathrm{mL}$ basal agar B, 0,01\% guiaicol), Hex medium for hexane degraders $(990 \mathrm{~mL}$ basal agar B, $1.3 \mathrm{~mL}$ filter-sterilized 99 parts hexane/1 part dishwashing detergent), Naph medium for naphthalene degraders (basal agar B with several crystals of naphthalene added to the lid of inverted plates and then sprayed with fast blue for degradation indication), and 2,4D medium for dichlorophenoxyacetate degraders (basal agar B supplemented with 2 mM 2,4-D).

Three atmospheric incubation conditions were used: an unmodified atmosphere in sealed plate bags, a propane-enriched aerobic atmosphere in sealed plate bags flushed daily with propane, and an anaerobic, propane-supplemented atmosphere in anaerobic jars scrubbed of oxygen with a palladium catalyst (BBL GasPak) and monitored for anaerobicity with a resazurin strip. The jars were injected with $100 \mathrm{~mL}$ propane through a septum. Plates were incubated in the dark at 5,15 , or $22^{\circ} \mathrm{C}$ until no new colonies appeared (up to 4 weeks).

Colony morphotypes were examined by visual features, such as colour and form of elevation and margins. A representative of each morphotype was aseptically restreaked on fresh media and restreaked up to three times or until considered isolated strain. Stocks of isolates were prepared by suspending a loopful of growth in $1.0 \mathrm{~mL} 28 \%(\mathrm{v} / \mathrm{v})$ glycerol and are stored at $-70^{\circ} \mathrm{C}$ in the University of Akureyri culture collection.

\section{S rRNA gene-based identification of cultured strains}


For each strain, $1 \mu 1$ of freezer stock was suspended in $25 \mu 1$ of lysis buffer $(1 \%$ Triton $\mathrm{x}-100,20 \mathrm{mM}$ Tris, $2 \mathrm{mM}$ EDTA, $\mathrm{pH} 8,0$ ) and incubated for 10 minutes at $95^{\circ} \mathrm{C}$ in the thermocyler (MJR PTC-200 thermocycler, MJ Research Inc. Massachusetts, USA). The lysis buffer solution (1 $\mu \mathrm{l})$, or $1 \mu \mathrm{l}$ of extracted DNA (using UltraClean® Microbial DNA Isolation Kit (MoBio Laboratories, Carlsbad, California, USA)), was used as a DNA template for Polymerase chain reaction (PCR) using Taq DNA-polymerase to amplify the DNA using the 'universal' bacterial primers $8 \mathrm{~F}$ (5'-

AGTTTGATCCTGGCTCAG'3) and 1522R: (5'-AAGGAGGTGATCCAGC CGCA-'3) (57).

The PCR reaction was conducted as follows: $95^{\circ} \mathrm{C}$ for $3 \mathrm{~min}$, followed by 35 cycles of $95^{\circ} \mathrm{C}$ for 30 sec, $50^{\circ} \mathrm{C}$ for $30 \mathrm{sec}$ and $68^{\circ} \mathrm{C}$ for $90 \mathrm{sec}$, then final extension at $68^{\circ} \mathrm{C}$ for $7 \mathrm{~min}$. The PCR products were loaded on $0,8 \%$ agarose gel and run at $100 \mathrm{~V}$ for approximately 30 minutes to verify the presence of approximately 1500-bp amplicons.

The PCR products were purified for sequencing using $22 \mu 1$ of sample in $10 \mu 1$ ExoSap Mix (mix

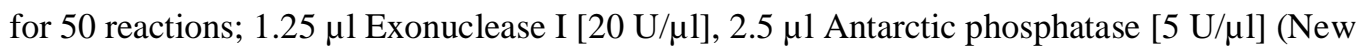
England BioLabs Inc.), $496.5 \mu 1$ distilled $\mathrm{H}_{2} \mathrm{O}$ ). The products were incubated at $37^{\circ} \mathrm{C}$ for 30 minutes and heated to $95^{\circ} \mathrm{C}$ for 5 minutes.

The purified PCR products were sequenced with BigDye terminator kit on Applied Biosystem 3130XL DNA analyser (Applied Biosystems, Foster City, California, USA) at Macrogen Europe, Amsterdam, the Netherlands. Two sequencing reactions were run for each strain, using the primers 519F (5'-CAGCAGCCGCGGTAATAC-'3) (58) and 926R (5'-CCGTCAATTCCTTTGAG TTT-'3) (59). The resulting sequences were trimmed using ABI Sequence Scanner (Applied Biosystems), the forward sequence and the reverse complement of the reverse sequence aligned and combined, and taxonomic identities obtained using the EzTaxon server (22).

\section{$\underline{\text { Results }}$}

Water chemical analysis revealed several differences in major components at the two sites (Table 2). Although the $\mathrm{pH}$ of the water did not differ significantly as judged by a two-tailed Student's t-test, electrical conductivity was nearly 12 -fold higher at the AEX site, significant at the $99.5 \%$ confidence 
level. The AEX site water contained more than 420-times as much silica as did the SX site water, and several other ions, such as sodium, potassium chloride and bromide were also found to be present at significantly higher levels at the AEX site, underscoring the more geothermal character of the environment (Table 2).

Headspace gas analysis revealed similar amounts of hydrocarbon gas at the two sites (Table 3). Although methane content was found $(n=3)$ to be lower at the AEX site than at the SX site, the difference was not deemed significant by a two-tailed Student's t-test (not shown). Isotope composition suggests a thermogenic origin of the AEX-site headspace gas, whereas a biogenic origin is suggested for the SX-site headspace gas (Table 3). Thermogenic origin of the AEX gas was further supported by a high methane/ethane ratio (17.8). Both the composition of the headspace gas and the methane isotope composition were similar to those reported by Ólafsson et al. for borehole gasses in the Skógalón area (18). EOM fractions showed difference in hydrocarbon content in terms of lowerchain hydrocarbons in AEX and higher amounts of longer-chain hydrocarbons at the SX site (Fig. 2).

\section{Bacterial community results.}

Four technical replicates from each study site were used to compare the microbial communities in the gas seepage pockmarks of Skógalón (SX) and Skógakíll (AEX). The DNA extraction yielded on average $2.8 \mu \mathrm{g} / \mathrm{ml}( \pm 0,3 \mu \mathrm{g} / \mathrm{ml})$ and the amplicon library generated on average $42.8 \mathrm{ng} / \mu \mathrm{L}( \pm 1,3$ $\mathrm{ng} / \mu \mathrm{L}$ ) of amplicons with the length of $587 \pm 5 \mathrm{bp}$. Over 4 million paired sequences, were analysed and trimmed to the average of 523,241 reads per sample with the length of $301 \mathrm{bp}$. A total of 595,137 reads generated the OTU table after filtering out chimeric sequences, where predicted OTUs were in total 26,786 OTUs (Table 4).

Alpha diversity metrics were measured at the depth of 60,000 sequences per sample. Based on rarefaction analysis, the number of OTUs had reached plateau at 25,000 sequences, meaning the dataset was sufficient to estimate the diversity of the bacterial communities in the natural seepage 
pockmarks. The species richness as estimated with Chao1 index and Shannon’s diversity index are shown in Table 4.

\section{Taxonomic composition}

The focus was set on analysing the most relative abundant taxa, so after filtering out chloroplast OTUs, the OTUs with the lowest combined abundance ( $<=1 \%$ of total reads) were omitted. A total of 14 bacterial phyla was observed as the most abundant at AEX and SX sites, divided up to 23 classes and 45 observed genera (Fig. 3). The Proteobacteria phylum had the most abundant OTUs at both AEX and SX sites, $28 \%$ and 30\%, respectively. At the AEX site, Proteobacteria was followed by Chloroflexi (22\%) and Aminicenantes (10\%) at phylum level. At the SX site, the Bacteroidetes had significantly higher abundance than in the AEX site, with relative abundance of $24 \%$, followed by

\section{Chloroflexi (13\%).}

The bacterial community structure differed between sites, but only one class, within the phylum of Aminicenantes was found by likelihood ratio analysis to be significantly more abundant at the AEX site than at the SX site. An unnamed order within the Bacteriodetes was found to be significantly more abundant at the SX site compared to the AEX. The family of Syntrophaceae within the class of Deltaproteobacteria was more abundant at the SX site with 2.6-fold higher relative abundance. OTUs of three genera within the Clostridia class had over 3.0-fold higher relative abundance at AEX than SX site.

\section{Cultured microbiota and isolates.}

Plate counts after 7 days at $22^{\circ} \mathrm{C}$ (Table 5) of samples from site SX indicated the presence of substantial communities of naphthalene and hexane degraders, particularly under aerobic conditions. One hundred and eighty-six colonies were restreaked for isolation in pure culture (Table 9 in supplements).

Putatively facultative chemoautotrophs were surprisingly numerous judging by growth on $\mathrm{Mn}$ media, but the extremely restrictive medium 9K only yielded a few colonies, all from sample OX06. 
Spraying colonies with fast blue confirmed the presence of alpha-naphthol in some of the colonies on Naph-agar, but not all. Strains OX0102 and OX0103 tested positive for naphthalene degradation by fast blue; strains OX0304 and OX0306 tested positive for 2,4-dichlorophenoxy acetic acid degradation by fast blue. One hundred and six strains have been identified by partial 16S rDNA sequencing using the Sanger method and found to comprise 38 genera in 8 classes (Table 6, Table 10 in supplements).

\section{$\underline{\text { Discussion }}$}

The study sites, AEX and SX, were found to be distinct in terms of geochemistry. The AEX site contained higher concentrations of silica, very similar to the concentrations of previous studies on geothermal activity in Öxarfjörður (18) indicating geothermal water coming from the pockmarks. The sodium chloride concentration was higher than in previous studies which implies a mixture of seawater with the geothermal water. However, the pockmarks at AEX are located in a river delta and water samples were taken at the pockmark surface so the intermixture of seawater is not surprising. The water chemistry at the SX site shows low concentration of silica indicating little or no geothermal activity and less intermixture of seawater than at AEX. The stable isotope ratio $\delta^{13} \mathrm{C}$ of methane also indicates a biogenic origin of the methane at SX, while at AEX the $\delta^{13} \mathrm{C}$ suggests a mixture of thermogenic and biogenic origin of methane, which can most likely be linked to microbial lignite utilization at the site as well as the geothermal activity previously described (18). The hydrocarbon content also shows more complex and longer-chain hydrocarbons at SX. This can be related to more vegetation and organic matter accumulation, in contrast with lower-chain hydrocarbons at the AEX site with less vegetation (Fig.2). These geochemical factors underline how disparate the two sites are: the AEX pockmarks containing geothermal groundwater with thermogenic methane generation and the SX pockmarks the result of biogenic natural gas accumulation. The location of the SX site and the lining up of the pockmarks can easily suggest thermogenic methane seepage at the site, but our analysis of the SX-site pockmarks explored in this study is more suggestive of marsh gas seepage, whereas at the AEX site, a thermogenic origin is more strongly supported. The difference in 
hydrocarbon content of the two sites, is most likely to explain the difference in biodiversity presented with biodiversity indices in Table 4. Howewer, further studies are needed to demonstrate the correlation between hydrocarbon content and biodiversity.

The seepage pockmarks were found to harbour diverse microbiotas consisting largely of anaerobic heterotrophs. Given the lack of visible vegetation at the AEX site, available organic matter seems likely to be restricted to the gas seep itself, to a large extent. This kind of environment thus contains a microbial community composed largely of facultative chemolithotrophs and oxidizers of methane, lighter alkanes, and aromatics. The inter-site diversity of both sampling sites was notable. However, several groups of bacteria were shown to vary in relative abundance between the two sampling sites, as discussed below.

\section{Hydrocarbon and methyl halide metabolism}

The high relative abundance of Dehalococcoidia in the microbial consortia at the study sites, particularly site AEX, is noteworthy and underscores the profound effect that petrochemical seepage has on the composition of the local microbiota. The class Dehalococcoidia contains at the present time only one validly described order (Dehalococcoidales), one family (Dehalococcoidaceae), and three genera (Dehalococcoides, Dehalobium and Dehalogenimonas), comprising a total of four species, all of which are capable of anaerobic reductive dehalogenation (23-27).

A large fraction of the dehalococcoidal OTUs in this study were found to be assignable to the order Dehalococcoidales (Table 7), where the majority (9120 of 9579) being further assignable to the family Dehalococcoidaceae, containing the described, dehalorespiring members of this class. In further support of dehalorespiration being an important process in the seepage pockmark microbiotas, genera known to contain facultative dehalorespirers, like the betaproteobacterial genus Dechloromonas (28) and the deltaproteobacterial genus Anaeromyxobacter (29), were significantly more abundant at the AEX site. Furthermore, cultured bacteria from the Öxfjörður seeps, while not including Dehalococcoidia, do include isolates assigned to genera known to include aerobic facultative dechlorinators, such as Dechloromonas and Shewanella (Table 7). 
The as-yet unnamed and uncharacterized order GIF9 was highly abundant in the AEX and SX microbiomes (Table 7) and may consist of bacteria that possess other metabolic pathways than just organohalide respiration. The order is suggested to be an important bacterial group for the degradation of organic matter in sediments (49). Thus, a recent metagenomic study indicated that some members of this group may be homoacetogenic fermenters that possess a complete Wood-Ljungdahl $\mathrm{CO}_{2}$ reduction pathway (31). It should thus be stressed that the presence of a large contingent of Dehalococcoidia, as was found to be the case in the present study, need not necessarily be indicative of dehlaorespiration constituting a major metabolic activity in the environment under study. Indeed, considerable variation in metabolic characteristics occurs in most well-characterized bacterial classes and hence it must be considered likely that other, perhaps non-dehalorespiring taxa remain to be characterized within this class.

Recently, it was suggested, in part because of the notable abundance of Dehalococcoides, that in certain Antarctic lakebeds, anaerobic methane oxidation may be fuelled by reductive dehalogenation (10). The results of the present study are suggestive of the presence of such an ecosystem in the methane seeps in the Öxarfjörður graben. Methyl halides are often associated with coal combustion (32), further suggesting subsurface interaction of geothermal matter with lignite as a source of chloromethane.

Also among abundant groups observed in the present study, the Atribacteria (group 'OP9') are often found to be predominant in methane-rich anaerobic environments such as marine sediments and subseafloor "mud volcanoes" $(43,44)$. Although they have not been directly linked to AOM in these environments, they have been suggested to mediate AOM in some cold seep environments (10). In general, the Atribacteria are thought to play heterotrophic roles, likely fermentative $(43,45)$, but a single-cell genomics study on representative Atribacteria suggests that these organisms may be indirectly responsible for methane production through the production of acetate or $\mathrm{CO}_{2}(43,46)$.

Another highly abundant class within the Chloroflexi was the Anaerolineae (Table 7), a class originally described as consisting of strictly anaerobic chemo-organotrophs (33), and frequently detected in subsurface environments (34-37). However, due to the scarcity of cultured 
representatives, the metabolic capabilities of this class have remained elusive. A recent study of seven single-cell genomes from deep submarine hydrothermal vent sediments indicated the presence of a Wood-Ljungdahl $\mathrm{CO}_{2}$ reduction pathway, as well as a number of $\mathrm{ABC}$ transporters, and in one case a putative reductive dehalogenase (38). In the present study, the Anaerolineae appear fairly diverse, with $81 \%$ of Chloroflexi paired-end reads being assigned to four orders: the Anaerolineales and three putative orders without cultured representation, envOPS12, GCA004, and SHA-20 (Table 7).

\section{Proteobacteria and the sulfur cycle}

Members of the Proteobacteria phylum observed in the seepage pockmarks mainly consisted of Deltaproteobacteria and Alphaproteobacteria (Table 8). The alphaproteobacterial fraction was fairly homogeneous, consisting mostly of reads assigned to the order Rhizobacteriales, of which $77 \%$ could be assigned to a single genus, Bosea, a genus of chemolithoheterotrophs noted for their ability to oxidize inorganic sulfur compounds (39). The deltaproteobacterial fraction was found to be more diverse although most of the OTUs could be assigned to either of two orders, the Syntrophobacterales and the Desulfobacterales (Table 8), both of which contain mostly, albeit not exclusively, sulfatereducing organisms.

The Syntrophobacterales, known to be frequently associated with anoxic aquatic environments (40), are significantly enriched in the SX marshland site as compared to the AEX site, perhaps reflecting an influx of marshland-associated bacteria into the seepage pockmark environment. Most of the Syntrophomonadales reads (77\%) can be assigned to the family Syntrophaceae, which contains both sulfate-reducing and non-sulfate-reducing bacteria (41). Many of the Syntrophaceae reads (59\%) could not be confidently assigned to genera, rendering the question of the importance of sulfate reduction of this taxon in the seepage pockmarks unresolved. However, taken together with the high abundance of the sulfate-reducing order Desulfobacterales, sulfate reduction is likely to be a major process in the seepage pockmarks, likely supporting AOM consortia. Families within Desulfobacterales have been reported to actively oxidize short and long chain alkanes and are suggested to be the key alkane degraders in marine seeps (42). Furthermore, considering the high 
abundance of the sulfur-oxidizing Bosea, we can surmise that Proteobacteria consitute an important driver of sulfur cycling within the seepage pockmark microbiota.

\section{Bioremediative potential of isolated bacterial strains}

Microbial communities containing facultative chemolithotrophs and hydrocarbon oxidizers, could be valuable for bioremediation of petroleum contamination in basaltic oligotrophic environments (54, 55) such as Icelandic beach environments. Previously it has been demonstrated that the microbial activity in Icelandic soils is more affected by substrate availability than temperature $(50,51)$, wich means the possibility of bioremediative strategies like biostimulation is quite possible. Screening environmental isolates for possible bioremediative capabilities is therefore meaningful for further research into potential bioremediation in contaminated seashore environments in Iceland. Two of the isolated strains showed degradation potential of naphthalene. Strain OX0102 was assigned to the genus Brevundimonas (Table 10 in supplements) and Strain OX0103 was most closely related to bacteria in the genus Rahnella (Table 10 in supplements), but strains from both genera have been isolated with high hydrocarbonoclastic activity in relation to the degradation of naphthalene $(52,53)$. Strains OX0304 and OX0306, both assigned by EzTaxon as Pseudomonas species (Table 10 in supplements), showed putative degradation of 2,4-dichlorophenoxy acetic acid. Furthermore, strain OX0627 was assigned as a member of Dechloromonas, but isolates from that genus are capable of anaerobic oxidation of benzene (30) and could possibly be used for bioremediation, as well as the isolated strains mentioned above. This substantiates the significance of isolated strains presented in the study for future research in Iceland, related to hydrocarbon degradation and bioremediation.

\section{Concluding remarks}

This study presents the first microbial community analysis of a gas seepage site in Iceland and compares the microbiomes of neighboring biogenic and thermogenic gas seepage pockmarks in the Jökulsá-á-Fjöllum river delta. It thus provides insights into microbial communities in these unusual environments and raises compelling questions on the connection between the gas origin and the 
pockmark microbiota, establishing the need for further geomicrobiological research in Icelandic natural gas seeps. The microbial communities associated with the pockmarks show higher biodiversity in the biogenic gas seep than in the thermogenic one, presenting a diverse microbiota that consists largely of anaerobic heterotrophs. The abundant taxa in the pockmarks indicate that the microbial community is most likely involved in hydrocarbon degradation linked to sulfur cycling and AOM, and the abundance of Dehalococcoidia suggests the presence of anaerobic reductive dehalogenation in natural gas seepage pockmarks of thermogenic origin. Several strains isolated in this study have demonstrable hydrocarbon-degrading activity, and thus comprise a pivotal resource for future studies in bioremediation and enviromental biotechnology in Iceland.

\section{Acknowledgments}

This work was funded by Orkustofnun and Orkurannsoknarsjodur Landsvirkjunar. We thank Geir Hansen \& Co. at Applied Petroleum Technology for their contribution, and we thank students Helga Helgadóttir and Silja Rúnarsdóttir for their work related to the research. Last but not least we would like to dedicate this research to our co-author, Pórarinn Sveinn Arnarson, who passed away during the submission process.

\section{$\underline{\text { References }}$}

1. Link WK. 1952. Significance of oil and gas seeps in world oil exploration. Am Assoc Pet Geol Bull 36:1505-1540.

2. Jones, V. T., \& Drozd RJ. 1983. Predictions of oil or gas potential by near-surface geochemistry. Am Assoc Pet Geol Bull 67:932-952.

3. Abrams MA, Dahdah NF. 2010. Surface sediment gases as indicators of subsurface hydrocarbons - examining the record in laboratory and field studies. Mar Pet Geol 27:273284.

4. Etiope G, Feyzullayev A, Baciu CL. 2009. Terrestrial methane seeps and mud volcanoes: A global perspective of gas origin. Mar Pet Geol 26:333-344. 
5. Zengler K, Richnow HH, Rosselló-Mora R, Michaelis W, Widdel F. 1999. Methane formation from long-chain alkanes by anaerobic microorganisms. Nature 401:266-269.

6. Martini AM, Budai JM, Walter LM, Schoell M. 1996. Microbial generation of economic accumulations of methane within a shallow organic-rich shale. Nature 383:155-158.

7. Ritter D, Vinson D, Barnhart E, Akob DM, Fields MW, Cunningham AB, Orem W, McIntosh JC. 2015. Enhanced microbial coalbed methane generation: A review of research, commercial activity, and remaining challenges. Int J Coal Geol 146:28-41.

8. Zhang CL, Lanoil B. 2004. Geomicrobiology and biogeochemistry of gas hydrates and cold seeps. Chem Geol 205:187-194.

9. Ettwig KF, Butler MK, Le Paslier D, Pelletier E, Mangenot S, Kuypers MMM, Schreiber F, Dutilh BE, Zedelius J, de Beer D, Gloerich J, Wessels HJCT, van Alen T, Luesken F, Wu ML, van de Pas-Schoonen KT, Op den Camp HJM, Janssen-Megens EM, Francoijs K-J, Stunnenberg H, Weissenbach J, Jetten MSM, Strous M. 2010. Nitrite-driven anaerobic methane oxidation by oxygenic bacteria. Nature 464:543-548.

10. Saxton MA, Samarkin VA, Schutte CA, Bowles MW, Madigan MT, Cadieux SB, Pratt LM, Joye SB. 2016. Biogeochemical and 16S rRNA gene sequence evidence supports a novel mode of anaerobic methanotrophy in permanently ice-covered Lake Fryxell, Antarctica. Limnol Oceanogr 61:S119-S130.

11. Mills HJ, Martinez RJ, Story S, Sobecky PA, Sobecky A. 2005. Characterization of Microbial Community Structure in Gulf of Mexico Gas Hydrates $\square$ : Comparative Analysis of DNA- and RNA-Derived Clone Libraries Characterization of Microbial Community Structure in Gulf of Mexico Gas Hydrates $\square$ : Comparative Analysis of DNA-. Appl Environ Microbiol 71:32353247.

12. Inagaki F, Nunoura T, Nakagawa S, Teske A, Lever M, Lauer A, Suzuki M, Takai K, Delwiche M, Colwell FS, Nealson KH, Horikoshi K, D’Hondt S, Jørgensen BB. 2006. Biogeographical distribution and diversity of microbes in methane hydrate-bearing deep marine sediments on the Pacific Ocean Margin. Proc Natl Acad Sci U S A 103:2815-20. 
13. Knittel K, Boetius A, Lemke A, Eilers H, Lochte K, Pfannkuche O, Linke P, Amann R. 2003. Activity, Distribution, and Diversity of Sulfate Reducers and Other Bacteria in Sediments above Gas Hydrate (Cascadia Margin, Oregon). Geomicrobiol J 20:269-294.

14. Niemann H, Lösekann T, de Beer D, Elvert M, Nadalig T, Knittel K, Amann R, Sauter EJ, Schlüter M, Klages M, Foucher JP, Boetius A. 2006. Novel microbial communities of the Haakon Mosby mud volcano and their role as a methane sink. Nature 443:854-858.

15. Flóvenz ÓG, Gunnarsson K. 1991. Seismic crustal structure in Iceland and surrounding area. Tectonophysics 189:1-17.

16. Gunnarsson K. 1998. Sedimentary basins of the N-Iceland shelf. Draft Version for Discussion (April-May 1998). Report OS-98014. Reykjavík.

17. Friðleifsson GÓ. 1994. Geothermal gradient and hydrothermal systems off North Iceland. Statement GÓF-94-05. Reykjavík.

18. Ólafsson M, Friðleifsson GÓ, Eiríksson J, Sigvaldason H, Ármansson H. 1993. On the origin of organic gas in Öxarfjörður, NE-Iceland. Report No. OS-93015/JHD-05. Reykjavík.

19. Richter B, Gunnarsson K. 2010. Overview of hydrocarbon related research in Tjörnes. GagnavefsjaIs.

31. Sæmundsson K, Hjartarson Á, Kaldal I, Sigurgeirsson MA, Kristinsson SG, S V. 2017. Jarðfræðikort af Norðurgosbelti. Nyrðri hluti. 1:100.000. Íslenskar Orkurannsóknir and Landsvirkjun., Reykjavík.

21. Silverman MP, Lundgren DG. 1959. Studies on the chemoautotrophic iron bacterium Ferrobacillus ferrooxidans. J Bacteriol 77:642-647.

22. Kim O-S, Cho Y-J, Lee K, Yoon S-H, Kim M, Na H, Park S-C, Jeon YS, Lee J-H, Yi H, Won S, Chun J. 2012. Introducing EzTaxon-e: a prokaryotic 16S rRNA gene sequence database with phylotypes that represent uncultured species. Int J Syst Evol Microbiol 62:716-21.

23. Löffler F, Yan J, Ritalahti K, Adrian L, Edwards E, Konstantinidis K, Müller J, Fullerton H, Zinder S SA. 2013. Dehalococcoides mccartyi gen. nov., sp. nov., obligately organohaliderespiring anaerobic bacteria relevant to halogen cycling and bioremediation, belong to a novel 
bacterial class, Dehalococcoidia classis nov., order Dehalococcoidales ord. nov. and famil. Int J Syst Evol Microbiol 63:625-635.

24. Bowman KS, Nobre MF, da Costa MS, Rainey F a, Moe WM. 2012. Dehalogenimonas alkenigignens sp. nov., a chlorinated alkane dehalogenating bacterium isolated from groundwater. Int J Syst Evol Microbiol.

25. Moe WM, Yan J, Nobre MF, da Costa MS, Rainey FA. 2009. Dehalogenimonas lykanthroporepellens gen. nov., sp. nov., a reductively dehalogenating bacterium isolated from chlorinated solvent-contaminated groundwater. Int J Syst Evol Microbiol 59:2692-2697.

26. May HD, Sowers KR. 2016. "Dehalobium chlorocoercia" DF-1-from discovery to application, p. 563-586. In Organohalide-Respiring Bacteria.

27. Nuzzo A, Negroni A, Zanaroli G, Fava F. 2017. Identification of two organohalide-respiring Dehalococcoidia associated to different dechlorination activities in PCB-impacted marine sediments. Microb Cell Fact 16:127.

28. Achenbach LA, Michaelidou U, Bruce RA, Fryman J, Coates JD. 2001. Dechloromonas agitata gen. nov., sp. nov. and Dechlorosoma suillum gen. nov., sp. nov., two novel environmentally dominant (per)chlorate-reducing bacteria and their phylogenetic position. Int J Syst Evol Microbiol 51:527-533.

29. Sanford RA, Cole JR, Tiedje JM. 2002. Characterization and description of Anaeromyxobacter dehalogenans gen. nov., sp. nov., an aryl-halorespiring facultative anaerobic myxobacterium. Appl Environ Microbiol 68:893-900.

30. Coates JD, Chakraborty R, Lack JG, O'Connor SM, Cole KA, Bender KS, Achenbach LA. 2001. Anaerobic benzene oxidation coupled to nitrate reduction in pure culture by two strains of Dechloromonas. Nature 411:1039-1043.

31. Hug LA, Castelle CJ, Wrighton KC, Thomas BC, Sharon I, Frischkorn KR, Williams KH, Tringe SG, Banfield JF. 2013. Community genomic analyses constrain the distribution of metabolic traits across the Chloroflexi phylum and indicate roles in sediment carbon cycling. Microbiome 1:22. 
32. McCulloch A, Aucott ML, Benkovitz CM, Graedel TE, Kleiman G, Midgley PM, Li Y-F. 1999. Global emissions of hydrogen chloride and chloromethane from coal combustion, incineration and industrial activities: Reactive Chlorine Emissions Inventory. J Geophys Res 104:8391-8403.

33. Yamada T, Sekiguchi Y, Hanada S, Imachi H, Ohashi A, Harada H, Kamagata Y. 2006. Anaerolinea thermolimosa sp. nov., Levilinea saccharolytica gen. nov., sp. nov. and Leptolinea tardivitalis gen. nov., sp. nov., novel filamentous anaerobes, and description of the new classes Anaerolineae classis nov. and Caldilineae classis nov. in the . Int J Syst Evol Microbiol $56: 1331-1340$.

34. Schippers A, Kock D, Höft C, Köweker G, Siegert M. 2012. Quantification of Microbial Communities in Subsurface Marine Sediments of the Black Sea and off Namibia. Front Microbiol 3:16.

35. Galand PE, Potvin M, Casamayor EO, Lovejoy C. 2010. Hydrography shapes bacterial biogeography of the deep Arctic Ocean. ISME J 4:564-576.

36. Kato S, Kobayashi C, Kakegawa T, Yamagishi A. 2009. Microbial communities in iron-silicarich microbial mats at deep-sea hydrothermal fields of the Southern Mariana Trough. Environ Microbiol 11:2094-2111.

37. Cleary DFR, Coelho FJRC, Oliveira V, Gomes NCM, Polónia ARM. 2017. Sediment depth and habitat as predictors of the diversity and composition of sediment bacterial communities in an inter-tidal estuarine environment. Mar Ecol 38:e12411.

38. Fullerton H, Moyer CL. 2016. Comparative Single-Cell Genomics of Chloroflexi from the Okinawa Trough Deep-Subsurface Biosphere. Appl Environ Microbiol 82:3000-3008.

39. Das SK. 2015. BoseaBergey's Manual of Systematics of Archaea and Bacteria. John Wiley \& Sons, Ltd.

40. Kuever J, Rainey FA, Widdel F. 2015. Syntrophobacterales ord. novBergey's Manual of Systematics of Archaea and Bacteria. John Wiley \& Sons, Ltd.

41. Kuever J, Rainey FA, Widdel F. 2015. Syntrophaceae fam. nov.Bergey’s Manual of 
Systematics of Archaea and Bacteria. John Wiley \& Sons, Ltd.

42. Kleindienst S, Herbst F-A, Stagars M, von Netzer F, von Bergen M, Seifert J, Peplies J, Amann R, Musat F, Lueders T, Knittel K. 2014. Diverse sulfate-reducing bacteria of the Desulfosarcina/Desulfococcus clade are the key alkane degraders at marine seeps. ISME J 8:2029-2044.

43. Carr SA, Orcutt BN, Mandernack KW, Spear JR. 2015. Abundant Atribacteria in deep marine sediment from the Adélie Basin, Antarctica. Front Microbiol 6:872.

44. Hoshino T, Toki T, Ijiri A, Morono Y, Machiyama H, Ashi J, Okamura K, Inagaki F. 2017. Atribacteria from the Subseafloor Sedimentary Biosphere Disperse to the Hydrosphere through Submarine Mud Volcanoes. Front Microbiol 8:1135.

45. Dodsworth JA, Blainey PC, Murugapiran SK, Swingley WD, Ross CA, Tringe SG, Chain PSG, Scholz MB, Lo C-C, Raymond J, Quake SR, Hedlund BP. 2013. Single-cell and metagenomic analyses indicate a fermentative and saccharolytic lifestyle for members of the OP9 lineage. Nat Commun 4:1854.

46. Nobu MK, Dodsworth JA, Murugapiran SK, Rinke C, Gies EA, Webster G, Schwientek P, Kille P, Parkes RJ, Sass H, Jørgensen BB, Weightman AJ, Liu W-T, Hallam SJ, Tsiamis G, Woyke T, Hedlund BP. 2016. Phylogeny and physiology of candidate phylum "Atribacteria" (OP9/JS1) inferred from cultivation-independent genomics. ISME J 10:273-8

47. Valentine DL. 2002. Biogeochemistry and microbial ecology of methane oxidation in anoxic environments: a review. Antonie Van Leeuwenhoek 81:271-282

48. Arnórsson S, Bjarnason JÖ, Giroud N, Gunnarsson I, Stefánsson A. 2006. Sampling and analysis of geothermal fluids. Geofluids 6:203-216.

49. Oni OE, Schmidt F, Miyatake T, Kasten S, Witt M, Hinrichs KU, Friedrich MW. 2015. Microbial communities and organic matter composition in surface and subsurface sediments of the Helgoland mud area, North Sea. Front Microbiol 6:1290.

50. Guicharnaud R, Arnalds O, Paton GI. 2010. Short term changes of microbial processes in Icelandic soils to increasing temperatures. Biogeosciences 7:671-82. 
51. Lehtinen T, Mikkonen A, Sigfusson B, Ólafsdóttir K, Ragnarsdóttir KV, Guicharnaud R. 2014. Bioremediation trial on aged PCB-polluted soils—a bench study in Iceland. Environ Sci Pollut Res 21:1759-68.

52. Mansur AA, Adetutu EM, Kadali KK, Morrison PD, Nurulita Y, Ball AS. 2014. Assessing the hydrocarbon degrading potential of indigenous bacteria isolated from crude oil tank bottom sludge and hydrocarbon-contaminated soil of Azzawiya oil refinery, Libya. Environ Sci Pollut Res 21:10725-35.

53. Ma Y, Wang L, Shao Z. 2006. Pseudomonas, the dominant polycyclic aromatic hydrocarbon $\square$ degrading bacteria isolated from Antarctic soils and the role of large plasmids in horizontal gene transfer. Environ Microbiol 8:455-65.

54. Markúsdóttir M, Heiðmarsson S, Eypórsdóttir A, Magnússon KP, Vilhelmsson O. 2013. The natural and anthropogenic microbiota of Glerá, a sub-arctic river in northeastern Iceland. Int Biodeterior Biodegradation 84:192-203.

55. Jóelsson JP, Friðjónsdóttir H, Vilhelmsson O. 2013. Bioprospecting a glacial river in Iceland for bacterial biopolymer degraders. Cold Reg Sci Technol 96:86-95.

56. Judd A, Hovland M. 2009. Seabed fluid flow: the impact on geology, biology and the marine environment. Cambridge University Press.

57. Edwards U, Rogall T, Blöcker H, Emde M, Böttger EC. 1989. Isolation and direct complete nucleotide determination of entire genes. Characterization of a gene coding for $16 \mathrm{~S}$ ribosomal RNA. Nucleic Acids Res 17:7843-7853.

58. Muyzer G, De Waal EC, Uitterlinden AG. 1993. Profiling of complex microbial populations by denaturing gradient gel electrophoresis analysis of polymerase chain reaction-amplified genes coding for 16S rRNA. Appl. Environ. Microbiol. 59:695-700.

59. Watanabe K, Kodama Y, Harayama S. 2001. Design and evaluation of PCR primers to amplify bacterial 16S ribosomal DNA fragments used for community fingerprinting. J. Microbiol. Methods 44:253-262. 
60. Porsteinsdóttir, G. V., Blischke, A., Sigurbjörnsdóttir, M. A., Óskarsson, F., Arnarson, P. S., Magnússon, K. P., and Vilhelmsson, O. (2019) Gas seepage pockmark microbiomes suggest the presence of sedimentary coal seams in the Öxarfjörður graben of NE-Iceland. Preprint at BioRxiv: BIORXIV/2018/348011. 
bioRxiv preprint doi: https://doi.org/10.1101/348011: this version posted July 15,2019 . The copyright holder for this preprint (which was not certified by peer review) is the author/funder, who has granted bioRxiv a license to display the preprint in perpetuity. It is made available under aCC-BY-ND 4.0 International license.

Table 1. Location and description of sampling sites. Temperature and $p H$ were measured in situ with a hand-held probe.

\begin{tabular}{|c|c|c|c|c|c|}
\hline Site & Location & Coordinates & Description & $\mathrm{pH}$ & $\mathrm{T}\left({ }^{\circ} \mathrm{C}\right)$ \\
\hline AEX-A & Skógakíll & $\begin{array}{l}6^{\circ} 10^{\circ} 2.250 \mathrm{~N} \\
16^{\circ} 33^{\prime} 59.687 \mathrm{~W}\end{array}$ & $\begin{array}{l}\text { Gas seepage } \\
\text { sediment }\end{array}$ & 6,4 & 35,2 \\
\hline AEX-B & Skógakíll & $\begin{array}{l}66^{\circ} 10^{\prime} 8.014 \mathrm{~N} \\
16^{\circ} 33^{\prime} 56.422 \mathrm{~W}\end{array}$ & $\begin{array}{l}\text { Gas seepage } \\
\text { water }\end{array}$ & 6,4 & 53,3 \\
\hline AEX-C & Skógakíll & $\begin{array}{l}66^{\circ} 10^{\prime} 12.029 \mathrm{~N} \\
16^{\circ} 33^{\prime} 56.998 \mathrm{~W}\end{array}$ & Mud-mire & ND & 30,4 \\
\hline AEX-D & Skógakíll & $\begin{array}{l}66^{\circ} 10^{\prime} 9.554 \mathrm{~N} \\
16^{\circ} 33^{\prime} 57.793 \mathrm{~W}\end{array}$ & Sand-mud & 6,4 & 19,3 \\
\hline SX-A & Skógalón & $\begin{array}{l}66^{\circ} 09.222 \mathrm{~N} \\
016^{\circ} 37.089 \mathrm{~W}\end{array}$ & $\begin{array}{l}\text { Lagoon } \\
\text { sediment }\end{array}$ & 8,5 & 12,1 \\
\hline SX-B & Skógalón & $\begin{array}{l}66^{\circ} 09.244 \mathrm{~N} \\
016^{\circ} 37.240 \mathrm{~W}\end{array}$ & Puddle water & 8,5 & 13,4 \\
\hline
\end{tabular}


Table 2. Major physicochemical characteristics ${ }^{l}$ of water from the two study sites.

\begin{tabular}{llll}
\hline & $\mathrm{AEX}$ & $\mathrm{SX}$ & \\
\hline $\begin{array}{l}\mathrm{pH} \text { at } 21^{\circ} \mathrm{C} \\
\begin{array}{l}\mathrm{C} \text { onductivity at } 25^{\circ} \mathrm{C} \\
\left(\mu \mathrm{Scm}^{-1}\right)\end{array}\end{array}$ & $7.57 \pm 0.31$ & $8.64 \pm 0.73$ & $(\mathrm{p}=0.19)$ \\
\hline $\mathrm{DIC}\left(\mathrm{as} \mathrm{ppm} \mathrm{CO}_{2}\right)$ & $44.8 \pm 31.0$ & $94.5 \pm 43.1$ & $(\mathrm{p}=0.32)$ \\
$\mathrm{SiO}_{2}(\mathrm{ppm})$ & $147.5 \pm 2.1$ & $0.35 \pm 0.07$ & $(\mathrm{p}=0.0001)$ \\
$\mathrm{Na}(\mathrm{ppm})$ & $1900 \pm 56.6$ & $107.4 \pm 57.5$ & $(\mathrm{p}=0.001)$ \\
$\mathrm{K}(\mathrm{ppm})$ & $104.9 \pm 18.6$ & $4.01 \pm 1.96$ & $(\mathrm{p}=0.02)$ \\
$\mathrm{Mg}(\mathrm{ppm})$ & $24.0 \pm 15.9$ & $17.8 \pm 10.5$ & $(\mathrm{p}=0.69)$ \\
$\mathrm{Ca}(\mathrm{ppm})$ & $311.5 \pm 111.0$ & $17.1 \pm 9.0$ & $(\mathrm{p}=0.06)$ \\
$\mathrm{F}(\mathrm{ppm})$ & $0.45 \pm 0.13$ & $0.21 \pm 0.01$ & $(\mathrm{p}=0.11)$ \\
$\mathrm{Cl}(\mathrm{ppm})$ & $3355 \pm 276$ & $169.4 \pm 105.5$ & $(\mathrm{p}=0.004)$ \\
$\mathrm{Br}(\mathrm{ppm})$ & $12.2 \pm 0.8$ & $0.34 \pm 0.31$ & $(\mathrm{p}=0.002)$ \\
$\mathrm{SO}_{4}(\mathrm{ppm})$ & $215 \pm 76.4$ & $5.13 \pm 0.60$ & $(\mathrm{p}=0.06)$ \\
\hline
\end{tabular}

${ }^{1}$ Dissolved sulphide was determined on-site by titration with mercuric acetate using dithizone as indicator (48). Dissolved inorganic carbon was determined by alkalinity titration and back-titration (48). Silica was analysed by colorimetric determination of a silica-molybdate complex at $410 \mathrm{~nm}$. Total dissolved solids were determined by gravimetry. Anions were determined by suppressed ion chromatography. Major metals were analysed by atomic absorption spectrometry. 
Table 3. Headspace gas analysis ${ }^{l}$ on sediment samples from seepage pockmarks at the two study sites. The concentrations are shown as parts of Total Hydrocarbon Gas (THCG).

\begin{tabular}{|c|c|c|}
\hline & $\mathrm{AEX}$ & SX \\
\hline $\mathrm{N}_{2}[\%$ total] & $39.2( \pm 31.5)$ & $81.2( \pm 2.62)$ \\
\hline $\mathrm{O}_{2}+\mathrm{Ar}[\%$ total $]$ & $8.46( \pm 8.53)$ & $14.10( \pm 5.66)$ \\
\hline ppm THCG & $5.09 \times 10^{5}\left( \pm 3.88 \times 10^{5}\right)$ & $0.389 \times 10^{5}\left( \pm 0.296 \times 10^{5}\right)$ \\
\hline $\mathrm{CO}_{2}[\% \mathrm{THCG}]$ & $99.9( \pm 0.23)$ & $93.2( \pm 1.77)$ \\
\hline Methane $\left(\mathrm{CH}_{4}\right)$ & $46.1 \times 10^{-3}\left( \pm 48.3 \times 10^{-3}\right)$ & $6.78( \pm 1.66)$ \\
\hline [\% THCG] & & \\
\hline $\begin{array}{l}\text { Ethane }\left(\mathrm{C}_{2} \mathrm{H}_{6}\right) \\
\text { [\% THCG] }\end{array}$ & $2.60 \times 10^{-3}\left( \pm 4.50 \times 10^{-3}\right)$ & $0( \pm 0)$ \\
\hline $\begin{array}{l}\text { Propane }\left(\mathrm{C}_{3} \mathrm{H}_{8}\right) \\
\text { [\% THCG] }\end{array}$ & $1.03 \times 10^{-3}\left( \pm 1.79 \times 10^{-3}\right)$ & $0( \pm 0)$ \\
\hline $\begin{array}{l}\text { iso-Pentane }\left(i-\mathrm{C}_{5} \mathrm{H}_{12}\right) \\
\text { [\% THCG] }\end{array}$ & $18.7 \times 10^{-3}\left( \pm 32.3 \times 10^{-3}\right)$ & $8.00 \times 10^{-3}\left( \pm 11.3 \times 10^{-3}\right)$ \\
\hline $\begin{array}{l}\text { Pentane }\left(n-\mathrm{C}_{5} \mathrm{H}_{12}\right) \\
{[\% \text { THCG] }}\end{array}$ & $73.7 \times 10^{-3}\left( \pm 127 \times 10^{-3}\right)$ & $49.5 \times 10^{-3}\left( \pm 70.0 \times 10^{-3}\right)$ \\
\hline $\begin{array}{l}\text { Benzene }\left(\mathrm{C}_{6} \mathrm{H}_{6}\right) \\
{[\% \mathrm{THCG}]}\end{array}$ & $3.80 \times 10^{-3}\left( \pm 6.24 \times 10^{-3}\right)$ & $7.15 \times 10^{-3}\left( \pm 5.45 \times 10^{-3}\right)$ \\
\hline Methane $\delta^{13} \mathrm{C}[\% \circ]$ & -26.6 & -63.2 \\
\hline $\mathrm{CO}_{2} \delta^{13} \mathrm{C}[\% \mathrm{o}]$ & -3.3 & nd \\
\hline
\end{tabular}

${ }^{1}$ Samples were extracted in dichloromethane/methanol, deasphaltened in pentane, and analysed by gas chromatography. 
bioRxiv preprint doi: https://doi org/10.1101/348011; this version posted July 15,2019 . The copyright holder for this preprint (which was not certified by peer review) is the author/funder, who has granted bioRxiv a license to display the preprint in perpetuity. It is made available under aCC-BY-ND 4.0 International license.

Table 4. Number of predicted operational taxanomic units (OTUs) and alpha diversity metrics as calculated at 25,000 sequences from the two study sites.

\begin{tabular}{lcccccc} 
& & & & \multicolumn{3}{c}{ Alpha diversity metrics } \\
\cline { 5 - 7 } & $\begin{array}{c}\text { Paired } \\
\text { seqs }\end{array}$ & $\begin{array}{c}\text { Reads in } \\
\text { OTUs }\end{array}$ & $\begin{array}{c}\text { Predict } \\
\text { OTUs }\end{array}$ & OTUs & Shannon & \multicolumn{1}{c}{ Chao1 } \\
\cline { 2 - 7 } $\mathbf{X}$ & 2.064 .234 & 307.384 & 14.019 & $3.461 \pm 623$ & $8.3 \pm 0.5$ & $3.980 \pm$ \\
SX & 2.121 .996 & 287.753 & 12.767 & $3.762 \pm 333$ & $9.1 \pm 0.2$ & $4.203 \pm$ \\
& & & & & &
\end{tabular}


bioRxiv preprint doi: https://doi.org/10.1101/348011; this version posted July 15,2019 . The copyright holder for this preprint (which was not certified by peer review) is the author/funder, who has granted bioRxiv a license to display the preprint in perpetuity. It is made available under aCC-BY-ND 4.0 International license.

Table 5. Colony-forming units per gram sediment sample after 7 days at $22^{\circ} \mathrm{C}$ on selective media.

\begin{tabular}{lcccccc} 
& Ox01 & Ox01 & Ox03 & Ox03 & Ox06 & Ox06 \\
\cline { 2 - 7 } & Aerobic & Anaerobi & Aerobic & Anaerobi & Aerobic & Anaerobi \\
& & $c$ & $c$ & $c$ \\
R2A & $1.4 \times 10^{5}$ & $2.8 \times 10^{4}$ & $5.0 \times 10^{5}$ & $2.4 \times 10^{5}$ & $1.7 \times 10^{7}$ & $5.0 \times 10^{6}$ \\
Naph & $2.0 \times 10^{3}$ & $<1 \times 10^{3}$ & $<1 \times 10^{3}$ & $<1 \times 10^{3}$ & $2.5 \times 10^{5}$ & $1.0 \times 10^{5}$ \\
Hex & $7.5 \times 10^{4}$ & $<1 \times 10^{3}$ & $2.0 \times 10^{5}$ & $<1 \times 10^{3}$ & $>2.5 \times 10^{5}$ & $2.0 \times 10^{5}$ \\
2,4-D & nd & nd & $<1 \times 10^{3}$ & $<1 \times 10^{3}$ & nd & nd \\
Mn & $9.3 \times 10^{4}$ & $5.0 \times 10^{3}$ & $2.0 \times 10^{5}$ & $<1 \times 10^{3}$ & $>2.5 \times 10^{5}$ & $7.5 \times 10^{4}$ \\
9K & $<1 \times 10^{3}$ & $<1 \times 10^{3}$ & $<1 \times 10^{3}$ & $<1 \times 10^{3}$ & $1.0 \times 10^{3}$ & $3.0 \times 10^{3}$ \\
Gui & nd & nd & nd & nd & $1.0 \times 10^{6}$ & $3.0 \times 10^{6}$
\end{tabular}


Table 6. Bacterial isolates and their taxonomic classification by partial 16S rRNA gene sequencing.

\begin{tabular}{|c|c|c|c|c|}
\hline \multirow[b]{2}{*}{ Strains } & \multirow{2}{*}{$\begin{array}{c}\text { GenBank accession } \\
\text { numbers }\end{array}$} & \multicolumn{3}{|c|}{ EzTaxon classification } \\
\hline & & Class & Order & Family \\
\hline SX0206, SX1205 & MG575948, MG575949 & Actinobacteria & Corynebacteriales & Nocardiaceae \\
\hline OX0615 & MG575950 & " & Micrococcales & Cellulomonadac \\
\hline OX0315, OX0319 & MG575951, MG575952 & ” & " & Microbacteriacı \\
\hline OX0117, OX0308, OX0313 & MG575953-MG575955 & " & " & Micrococcaceat \\
\hline OX0107 & MG575956 & " & ” & " \\
\hline OX0614 & MG575957 & " & " & Sanguibacteracı \\
\hline OX0316 & MG575958 & " & Streptomycetales & Streptomycetace \\
\hline OX0104, OX0118 & MG575959, MG575960 & Cytophagia & Cytophagales & Cyclobacteriact \\
\hline $\begin{array}{l}\text { OX0108, OX0126, OX0312 } \\
\text { OX0623, OX0125, OX0129, OX0311, } \\
\text { OX0122, OX0123, OX0314, OX0127 }\end{array}$ & $\begin{array}{l}\text { MG575961-MG575963 } \\
\text { MG575964-MG575971 }\end{array}$ & Flavobacteriia & Flavobacteriales & Flavobacteriact \\
\hline $\begin{array}{l}\text { OX0625 } \\
\text { OX1213, OX2513, OX1505, OX2509, } \\
\text { OX1011, OX1604, OX1805, OX1004, } \\
\text { OX1006, OX1007, OX1210, OX1212, } \\
\text { OX2308, OX2309, OX2506 }\end{array}$ & $\begin{array}{l}\text { MG575972 } \\
\text { MG575973 } \\
\text { MG575987 }\end{array}$ & Sphingobacteria & Sphingobacteriales & Sphingobacteric \\
\hline $\begin{array}{l}\text { OX0317 } \\
\text { OX2205, OX0307, OX2310, OX0301, } \\
\text { OX0302 }\end{array}$ & $\begin{array}{l}\text { MG575988 } \\
\text { MG575989 } \\
\text { MG575993 }\end{array}$ & ” & " & Paenibacillacea \\
\hline OX0310 & MG575994 & " & " & Planococcaceat \\
\hline $\begin{array}{l}\text { OX0626 } \\
\text { OX1107, OX1109, OX2515, OX2106, } \\
\text { OX2313 }\end{array}$ & $\begin{array}{l}\text { MG575995 } \\
\text { MG575996-MG576000 }\end{array}$ & " & Lactobacillales & Staphylococcac \\
\hline OX0102, OX2008, OX0309 & MG576001-MG576003 & Alphaproteobacteria & Caulobacterales & Caulobacterace \\
\hline OX0106, OX1214, OX0119, SX1214 & MG576004-MG576007 & “ & Rhizobiales & Rhizobiaceae \\
\hline OX0632 & MG576008 & " & Rhodobacterales & Rhodobacterace \\
\hline OX1314 & MG576009 & ” & " & " \\
\hline SX0604 & MG576010 & " & Sphingomonadales & Erythrobacterac \\
\hline OX0620 & MG576011 & " & " & Sphingomonada \\
\hline OX1313, OX1403, OX1702, OX1216 & MG576012-MG576015 & Betaproteobacteria & Burkholderiales & Burkholderiaceı \\
\hline OX0105, OX0120, OX0124 & MG576016-MG576018 & " & " & Comamonadace \\
\hline OX0630, OX0321 & MG576019, MG576020 & ” & " & " \\
\hline OX0130 & MG576021 & " & " & ” \\
\hline OX0611 & MG576022 & " & " & incertae sedis \\
\hline $\begin{array}{l}\text { OX0627 } \\
\text { OX0617, OX0622, SX0303, OX0110, } \\
\text { OX0112, OX0612 }\end{array}$ & $\begin{array}{l}\text { MG576023 } \\
\text { MG576024-MG576029 }\end{array}$ & Gammaproteobacteria & Rhodocyclales & Rhodocyclaceat \\
\hline OX0619 & MG576030 & " & Alteromonadales & Shewanellaceae \\
\hline OX1909, OX1208 & MG576031-MG576032 & ” & Chromatiales & Chromatiaceae \\
\hline OX1012 & MG576033 & " & Enterobacteriales & Enterobacteriac \\
\hline OX0103, OX0101 & MG576034-MG576035 & " & ” & ” \\
\hline OX0604, OX0606, OX0607 & MG576036-MG576038 & “ & " & “' \\
\hline OX0601, OX0621 & MG576039-MG576040 & ” & Pseudomonadales & Moraxellaceae \\
\hline
\end{tabular}


bioRxiv preprint doi: https://doi.org/10.1101/348011; this version posted July 15,2019 . The copyright holder for this preprint (which was not certified by peer review) is the author/funder, who has granted bioRxiv a license to display the preprint in perpetuity. It is made available under aCC-BY-ND 4.0 International license.

OX1807, OX1808, OX0306, OX0322,

OX1110, OX0613, SX0305, SX0307,

SX1216, SX0304, OX0631, SX1213,

OX0304 
Table 7. Fractional abundance of Chloroflexi classes and orders in the seepage pockmarks microbiomes as determined with amplicon sequencing.

\begin{tabular}{|c|c|c|c|c|c|}
\hline Class & $\underset{1}{\mathrm{AEX}}$ & $\mathrm{SX}^{1}$ & Order & ${ }_{2}^{\mathrm{AEX}}$ & $\mathrm{SX}^{2}$ \\
\hline \multirow[t]{7}{*}{ Anaerolineae } & 0.65 & $\begin{array}{l}0.8 \\
7\end{array}$ & & & \\
\hline & & & Anaerolineales & 0.62 & $\begin{array}{l}0.9 \\
4\end{array}$ \\
\hline & & & Caldilineales & 0.02 & $\begin{array}{l}0.0 \\
0\end{array}$ \\
\hline & & & 'MSB-5B2' & 0.07 & $\begin{array}{l}\mathbf{0 . 0} \\
\mathbf{0}\end{array}$ \\
\hline & & & 'SBR1031' & 0.08 & $\begin{array}{l}0.0 \\
1\end{array}$ \\
\hline & & & 'RBG-13-54-9’ & 0.02 & $\begin{array}{l}0,0 \\
1\end{array}$ \\
\hline & & & Others & 0.19 & $\begin{array}{l}0.0 \\
4\end{array}$ \\
\hline \multirow[t]{5}{*}{$\begin{array}{l}\text { Dehalococcoidi } \\
a\end{array}$} & 0.30 & $\begin{array}{l}0.0 \\
8\end{array}$ & & & \\
\hline & & & $\begin{array}{l}\text { Dehalococcoidale } \\
S\end{array}$ & 0.02 & $\begin{array}{l}0.2 \\
2\end{array}$ \\
\hline & & & ‘GIF9’ & 0.70 & $\begin{array}{l}0.2 \\
6\end{array}$ \\
\hline & & & 'FS117-23B-02' & 0.06 & $\begin{array}{l}\mathbf{0 . 0} \\
2\end{array}$ \\
\hline & & & Others & 0.22 & $\begin{array}{l}0.5 \\
0\end{array}$ \\
\hline 'KD4-96’ & 0.02 & $\begin{array}{l}0.0 \\
4\end{array}$ & & & \\
\hline Others & 0.03 & $\begin{array}{l}0.0 \\
1\end{array}$ & & & \\
\hline
\end{tabular}

${ }^{1}$ Fraction of Chloroflexi paired-end sequences (total of 86,729 paired-end reads). Figures in bold indicate a significant difference between the AEX and SX microbiota by a two-tailed two-sample Student's $t$-test $(\mathrm{p}<0.05)$.

${ }^{2}$ Fraction of class-level paired-end sequences (total of 44,384 paired-end Anaerolineae reads and 36,549 paired-end Dehalococcoidia reads). Figures in bold indicate a significant difference between the AEX and SX microbiota by a two-tailed two-sample Student's $t$-test $(\mathrm{p}<0.05)$. 
Table 8. Fractional abundance of Proteobacteria classes and orders in the seepage pockmarks microbiomes as determined with amplicon sequencing.

\begin{tabular}{|c|c|c|c|c|c|}
\hline Class & $\mathrm{AEX}^{1}$ & $\mathrm{SX}^{1}$ & Order & $\mathrm{AEX}^{2}$ & $\mathrm{SX}^{2}$ \\
\hline \multirow{8}{*}{$\begin{array}{l}\text { Delta- } \\
\text { proteobacteria }\end{array}$} & 0.51 & 0.23 & & & \\
\hline & & & Syntrophobacterales & 0.53 & 0.70 \\
\hline & & & Desulfobacterales & 0.08 & 0.00 \\
\hline & & & Myxococcales & 0.02 & 0.02 \\
\hline & & & Desulfarculales & 0.07 & 0.00 \\
\hline & & & Desulfuromonadales & 0.01 & 0.01 \\
\hline & & & 'Sva0485' & 0.18 & 0.16 \\
\hline & & & Others & 0.11 & 0.11 \\
\hline \multirow{4}{*}{$\begin{array}{l}\text { Alpha- } \\
\text { proteobacteria }\end{array}$} & 0.22 & 0.10 & & & \\
\hline & & & Rhizobiales & 0.76 & 0.96 \\
\hline & & & Rhodobacterales & 0.09 & 0.01 \\
\hline & & & Others & 0.15 & 0.03 \\
\hline \multirow{3}{*}{$\begin{array}{l}\text { Gamma- } \\
\text { proteobacteria }\end{array}$} & 0.27 & 0.08 & & & \\
\hline & & & Betaproteobacteriales & 0.35 & 0.49 \\
\hline & & & Other & 0.65 & 0.51 \\
\hline
\end{tabular}

${ }^{1}$ Fraction of Proteobacteria paired-end sequences (total of 152,153 paired-end reads). Figures in bold indicate a significant difference between the AEX and SX microbiota by a two-tailed twosample Student's $t$-test $(\mathrm{p}<0.05)$.

${ }^{2}$ Fraction of class-level paired-end sequences (total of 83,764 paired-end Deltaproteobacteria reads and 43,823 paired-end Alphaproteobacteria reads). Figures in bold indicate a significant difference between the AEX and SX microbiota by a two-tailed two-sample Student's $t$-test $(\mathrm{p}<0.05)$. 
bioRxiv preprint doi: https://doi org/10.1101/348011; this version posted July 15,2019. The copyright holder for this preprint (which was not certified by peer review) is the author/funder, who has granted bioRxiv a license to display the preprint in perpetuity. It is made available under aCC-BY-ND 4.0 International license.

Fig. 1. A map of the study area showing the AEX sampling sites (blue squares) and the SX sites (orange circles). Black diamonds indicate geothermal boreholes. Faults are inferred from the works of Samundsson et al. (31) and Ólafsson et al. (18). The insert shows the location of the study area in Iceland and the volcanic rift zone, bounded by the solid lines.

Fig. 2. Hydrocarbon content in sediment samples from the natural gas seepage pockmarks. Extractable organic matter (EOM) concentration as determined by gas chromatography is compared between the AEX (dark columns) and SX (light columns) study sites (two samples per site). Error bars are omitted for clarity.

Fig. 3. Bacterial community structure in natural gas seepage pockmarks at Skógakíll (AEX) and Skógalón $(S X)$ sites, presented as the relative abundance of bacterial phyla from amplicon sequencing of V3-V4 in $16 S$ rDNA. Operational taxanomic units (OTUs) with relative abundance lower than 0.1 were omitted. 


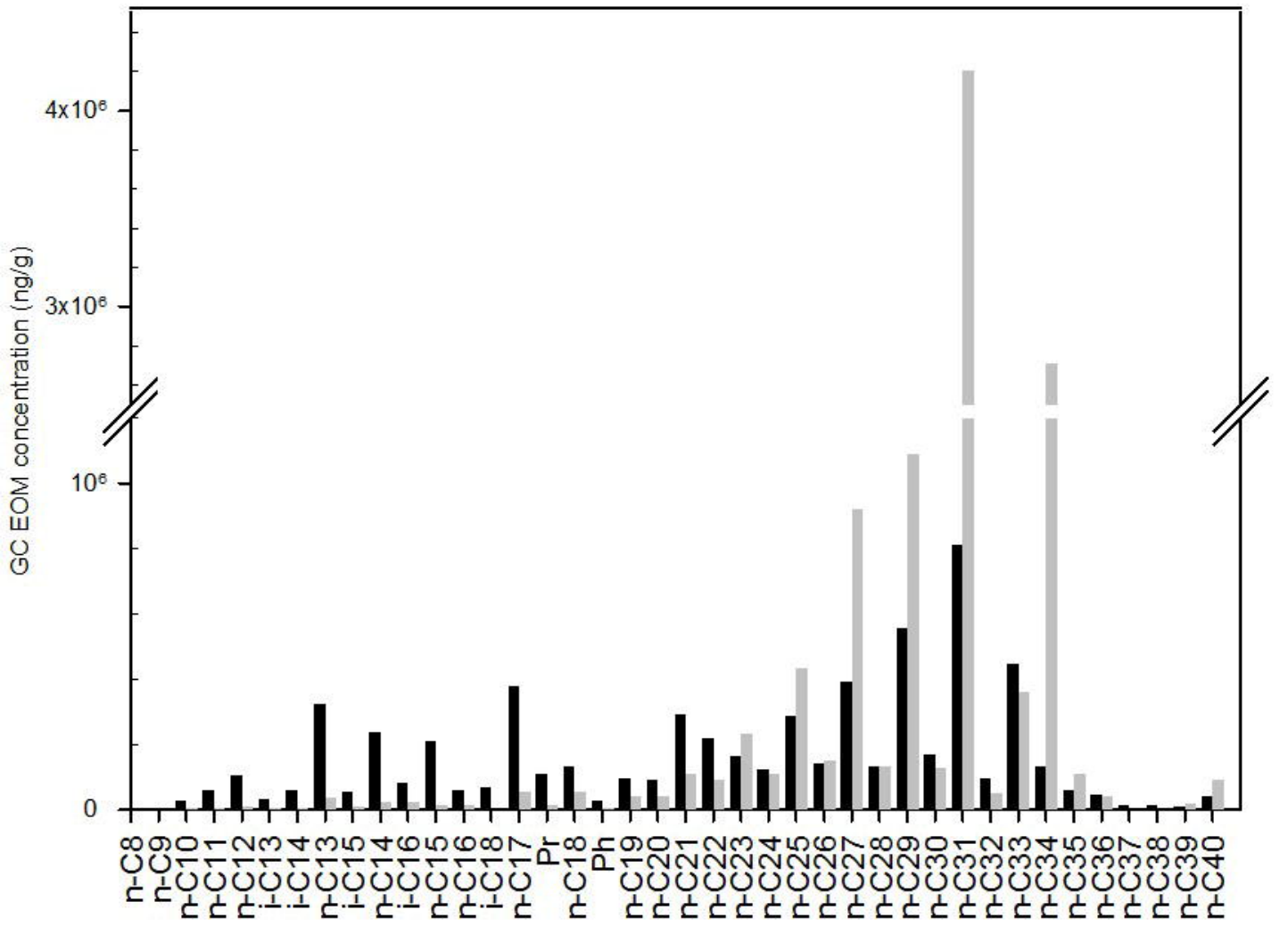




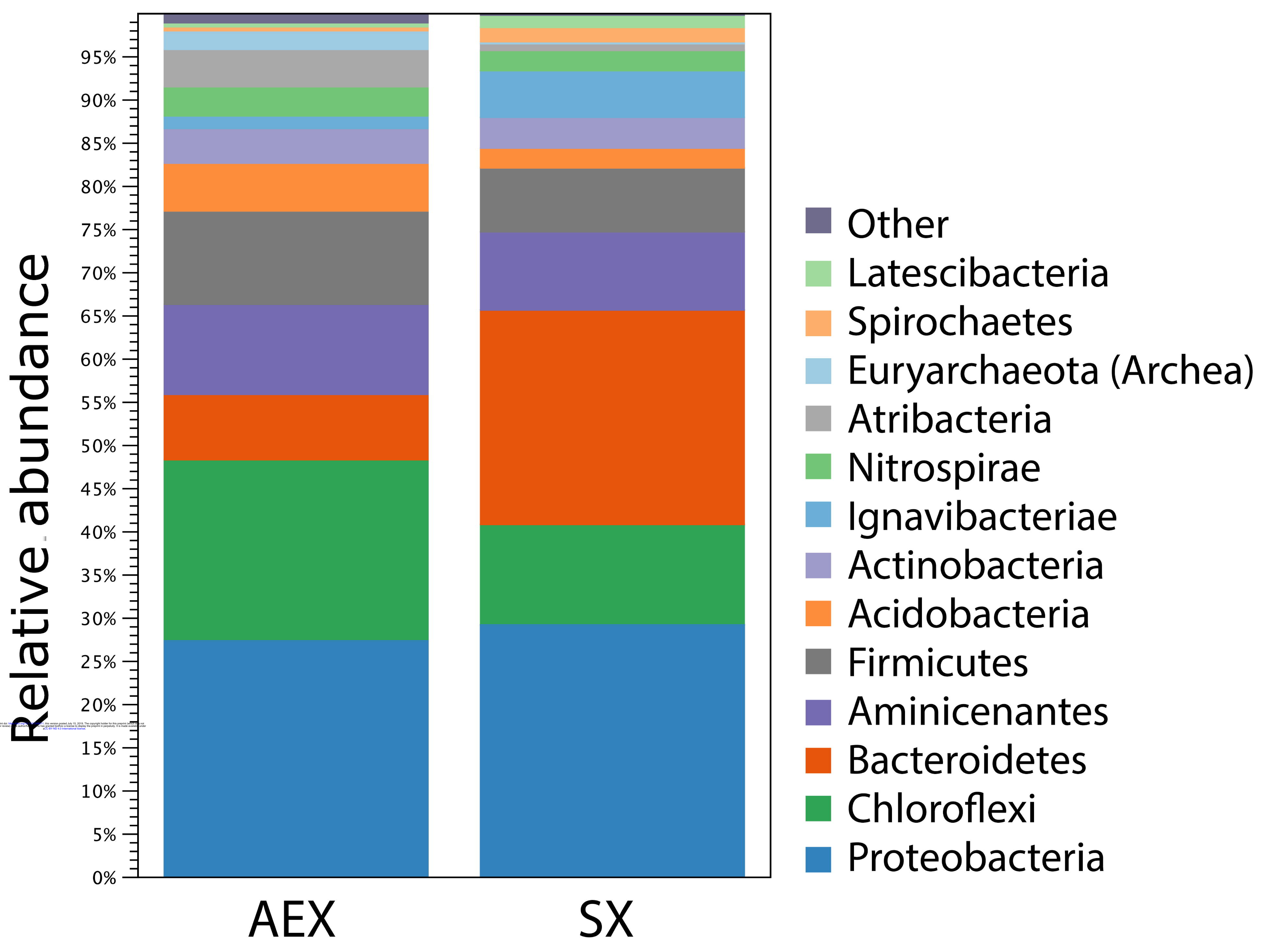

